\title{
'FORTUNATELY WE IN VictORIA ARE NOT IN THAT UK SITUATION': AUSTRALIAN AND UNITED KINGDOM Legal Perspectives on Plea BARGAINING REFORM
}

\author{
ASHER FLYNN*
}

The polarisation between consistency, controls and the unscrutinised discretionary powers held by criminal justice agencies is a complex issue that transcends jurisdictions. In the Australian State of Victoria, this conflict is particularly evident in the prosecutor's decision-making powers in the plea bargaining process, because these powers are not subject to scrutiny and the decisions made under them are not transparent. Furthermore, plea bargaining itself is a non-formalised and unscrutinised method of case resolution. While the use of discretion is an important component of prosecutorial work, it is the potentially individualised and idiosyncratic nature of unscrutinised discretionary decisions that results in plea bargaining and prosecutorial decision-making in Victoria giving rise to perceptions of inappropriateness and misconduct. Drawing upon the voices of Victorian and United Kingdom legal professionals, this article critically analyses the controls placed on United Kingdom prosecutors by the Attorney General's Guidelines on the Acceptance of Pleas and the Prosecutor's Role in the Sentencing Exercise 2009 (UK), and considers whether similar guidelines could be implemented in Victoria to redress problems surrounding the idiosyncratic nature of prosecutorial decisionmaking in plea bargaining. By offering a unique insight into the perspectives of those involved in plea bargaining, this article explores the benefits of implementing a transparent and scrutinised control on prosecutorial discretion in plea bargaining, and considers whether this would in turn offer greater safeguards, consistency and transparency of prosecutorial decision-making in Victoria.

\footnotetext{
* Lecturer in Criminology, School of Political and Social Inquiry, Monash University, Clayton Campus, Victoria 3800. Email correspondence: asher.flynn@monash.edu.
} 


\section{INTRODUCTION}

The tendency nowadays is to introduce more control rather than less, more control in every area. Like with victims, everything is automated by the Victims' Charter [Act 2006 (Vic)] now... There are issues with discretion being exercised now. A discretionary decision is made and someone says why? So there is a focus on reducing discretion. There is scope there [to reduce discretion] but you need to have some, it just requires a bit of finesse that hasn't been worked out yet ... So there is a tendency to implement controls. Whether that is good or bad, I don't know. (Prosecutor J) ${ }^{1}$

The polarisation between discretion and rules within the operation of criminal justice processes, and the resulting concerns surrounding the discretionary powers held by criminal justice agencies, have fuelled movements within Australia over the last 35 years - and since the late 1960s in the United States, United Kingdom (UK) and Canada — towards increasing the transparency of criminal justice processes and the conduct of those involved within them. ${ }^{2}$ In particular, such reforms have sought to control and scrutinise the discretionary powers of criminal justice agencies on the basis that this will increase public confidence, offer transparency, and improve (perceptions of) equality within legal systems. This movement is particularly noticeable in the UK, where legislation and mandatory guidelines direct the actions of criminal justice agencies in almost all aspects of criminal proceedings. ${ }^{3}$ The Attorney General's Guidelines on the Acceptance of Pleas and the Prosecutor's Role in the Sentencing Exercise 2009 (UK) ('Guidelines'), a policy which regulates prosecutorial conduct in the plea bargaining process, provides an example of such developments, and highlights the strong public interest and transparent

\footnotetext{
${ }^{1}$ Prosecutor J was a participant in the author's three-year study examining the justifications for formalising Victorian plea bargaining practices.

${ }^{2}$ Katja Franko Aas, Sentencing in the Age of Information: From Faust to Macintosh (Glasshouse Press, 2005); Abraham S Blumberg, Criminal Justice (Quadrangle Books, 1967); Kenneth Culp Davis, Discretionary Justice: A Preliminary Inquiry (Louisiana State University Press, 1969); David Dixon, Law in Policing: Legal Regulation and Police Practices (Clarendon Press, 1997); Oonagh E Fitzgerald, The Guilty Plea and Summary Justice: A Guide for Practitioners (Carswell, 1990); Robert A Kagan, 'Regulators and Regulatory Processes' in Austin Sarat (ed), The Blackwell Companion to Law and Society (Blackwell Publishing, 2004) 212; Cyrus Tata, 'Transformation, Resistance, and Legitimacy: The Role of Pre-Sentence Reports in the Production (and Disruption) of Guilt and Guilty Pleas' (Speech delivered at the European Society of Criminology Annual Conference, Edinburgh, Scotland, 2-5 September 2008) $<$ http://staff.law.strath.ac.uk/staff/cyrus_tata/ public/Role $\% 20$ of $\% 20$ the $\% 20$ SER $\% 20$ in $\% 20$ Facilitating $\% 20$ Guilt $\% 20$ ESC $\% 20$ Webpaper $\%$ 20.pdf>.

3 Aas, above n 2; Denis James Galligan, Discretionary Powers: A Legal Study of Official Discretion (Clarendon Press, 1986).
} 
roles of UK prosecutors in the otherwise generally hidden processes of plea bargaining and prosecutorial decision-making. ${ }^{4}$

This article explores the UK Guidelines and considers whether a similar reform could be implemented in a comparable, common law system in the Australian State of Victoria. The article particularly focuses on issues of transparency, prosecutorial resource expenditure, the pressures that accused persons face to plead guilty, and the pressures that prosecutors endure to engage in plea bargaining discussions. ${ }^{5}$ Aside from sharing a common law system of justice, both the Victorian and the UK justice systems are facing mounting pressures from an increase in criminal prosecutions, combined with a lack of sufficient resources and limited efficiency levels across all courts. The results of this have led to an (empirically perceived) rise in the use of early resolution mechanisms, particularly that of plea bargaining discussions between counsel to facilitate and encourage accused persons to make an early pleading decision. The approaches of the jurisdictions to holding prosecutors accountable for these decisions, however, have differed significantly, thus providing an interesting basis for a comparative analysis of the two systems.

Drawing from the voices of Australian and UK legal professionals, this article identifies some of the main benefits of the Guidelines, particularly in regard to greater transparency and accountability of prosecutorial decision-making. However it also recognises their limitations in potentially encroaching upon judicial independence in sentencing and further expending prosecutorial resources. This article argues that implementing the Guidelines in Victoria would be beneficial in making transparent prosecutorial conduct in plea bargaining. Such transparency would minimise some limitations arising from the private nature of plea discussions, particularly in reducing the negative assumptions associated with prosecutorial motivations for entering into and

4 John B Bishop, Prosecution Without Trial (Butterworths, 1989); Kerry Carrington and Russell Hogg, 'Critical Criminologies: An Introduction', in Kerry Carrington and Russell Hogg (eds), Critical Criminology: Issues, Debates, Challenges (Willan Publishing, 2002); John Jay Douglass, Ethical Issues in Prosecution (National College of District Attorneys, University of Houston Law Center, 1988); Rowena Johns, 'Victims of Crime: Plea Bargains, Compensation, Victim Impact Statements and Support Services' (Briefing Paper No 10/02, NSW Parliamentary Library Research Service, June 2002) <http://www. parliament.nsw.gov.au/prod/parlment/publications.nsf/0/578c6f10c6d98565ca256ecf00083b4 d/\$FILE/10-02.pdf>; Mike McConville, Andrew Sanders and Roger Leng, The Case for the Prosecution: Police Suspects and the Construction of Criminality (Routledge, 1991).

${ }^{5}$ For the purpose of this article, only the sections of the Guidelines that are directly relevant to prosecutorial discretion and plea bargaining - that is, the discussions between the prosecution and the defence practitioner(s) - are explored. 
accepting plea deals. ${ }^{6}$ However, the article recommends against the full implementation of like guidelines, suggesting that this would further overburden and waste prosecutorial pre-trial preparation time, possibly hinder the occurrence of plea discussions, and potentially encroach upon judicial independence in sentencing.

Providing a unique insight into the perspectives of Australian and United Kingdom legal professionals, and using a similar framework to that of Tata's analysis of judicial craftwork within the UK, ${ }^{7}$ this article contends that the polarisation between discretion and rules is, at least to some extent, archaic. Thus, rather than being labelled as contradictory, discretion and control, or 'rules', should work in conjunction with each other to increase perceptions of equality, transparency and accountability within criminal justice processes, particularly within the practice of plea bargaining. ${ }^{8}$ This article thus contends that it is not the existence of prosecutorial discretion per se that is the key problem in Victorian plea bargaining practices; it is the potentially idiosyncratic nature of the discretionary decisions that requires addressing through the implementation of a more transparent and scrutinised control mechanism, such as the Guidelines.

\section{Methodology OVerview}

This article draws upon the findings of a three-year study which examined the informality of plea bargaining and prosecutorial decision-making in Victoria. Fifty-eight semi-structured interviews were conducted with 46 participants in 2007, 2008 and 2009 in Victoria and London ( $\mathrm{n}=11$ defence [all Victorian]; $\mathrm{n}=23$ prosecutors $[\mathrm{n}=15$ Victorian, $\mathrm{n}=4 \mathrm{UK})] \mathrm{n}=7$ judiciary [all Victorian] and; $\mathrm{n}=5$ advisors [ $\mathrm{n}=2$ Victorian, $\mathrm{n}=3 \mathrm{UK}]$ ). The interview data shed light on the perspectives of legal parties and advisors, including representatives from the Victorian State Office of Public Prosecutions (OPP), Melbourne metropolitan criminal courts, the Criminal Bar Association, Victoria Legal Aid, the Victorian Attorney-General's Department, the UK Office of the Attorney General, the Crown Prosecutorial Service (CPS) and statutory bodies such as the Victorian Sentencing Advisory Council.

\footnotetext{
${ }^{6}$ Douglass, above n 4; Johns, above n 4; Peter H Solomon, Criminal Justice Policy, from Research to Reform (Butterworths, 1983).

${ }^{7}$ Cyrus Tata, 'Sentencing as Craftwork and the Binary Epistemologies of the Discretionary Decision Process' (2007) 16(3) Social and Legal Studies 425, 429.

${ }^{8}$ Ibid.
} 
The participants were representative of a range of experience and seniority, ranging from articled clerks $(n=1)$, instructing or junior solicitors $(n=6)$, Crown prosecutors and Program Managers $(\mathrm{n}=8)$, to education and development staff $(\mathrm{n}=4)$, Witness Assistance Service counsellors $(\mathrm{n}=2)$, Legal Aid solicitors and barristers $(n=4)$, Queens and Senior Counsel $(n=9)$, Magistrates $(n=1)$, Judges $(n=4)$ and Justices $(n=2)$. In order to maintain confidentiality, participants are assigned pseudonyms based on their profession and are referred to as Prosecutor, Judiciary, Defence or Advisor, followed by a randomly assigned sequential letter: for example, Prosecutor A, Advisor C. To illustrate the geographical location of the participant, all UK participants have the abbreviation ' $U K$ ' cited in brackets.

Semi-structured interviews were selected because they are positioned between the ordered technique of structured interviews and the flexible, free-flowing style of in-depth interviews. The questions were thus structured to allow for comparative analysis of responses, while still allowing sufficient flexibility for the interviewer to probe beyond the questions to seek elaboration and clarification. ${ }^{9}$ The participants were asked questions from one of two interview schedules, depending on their geographical location. Each schedule was divided into eleven topic areas, and combined direct and open-ended questions to encourage the expansion of personal opinions, while still allowing for a comparative analysis of responses. ${ }^{10}$ The questions were also selected according to the professional role of the participant. Thus not all participants were asked every question on the interview schedule. Consequently, when participant responses are analysed, the number of participants who were asked the question is often cited in conjunction with the number of participants who supported or opposed the view. For example, although 23 prosecutorial participants were interviewed, the analysis may state that ten out of twelve prosecutorial participants supported a particular view, because only twelve prosecutors were asked to comment on this issue.

Of most importance in the context of this discussion, the UK participants were asked to comment on the benefits and limitations of the Guidelines, based on their direct engagement with them, and then consider their applicability to a Victorian jurisdiction. The Victorian participants were asked to comment on

9 Fiona Devine and Sue Heath, Sociological Research Methods in Context (Palgrave Macmillan, 1999); Irving Seidman, Interviewing as Qualitative Research: A Guide for Researchers in Education and the Social Sciences (Teachers College Press, $2^{\text {nd }}$ ed, 1998).

10 The eleven topic areas included: defining plea bargaining (in Victoria/in the United Kingdom); benefits of plea bargaining; limitations of plea bargaining; the pre-trial process; court inefficiency and delay; sentence leniency and sentence discounts; sentence indications; victims, their role and rights; accused persons, their role and rights; non-transparency in discretionary decisions and; law reform. 
what they perceived to be the benefits and limitations of the Guidelines both as they operate in the UK, and as they would operate should they be implemented in Victoria. The interview data included descriptions of behaviour, institutions, court processes, appearances, actions, interactions, personal narratives and accounts. The emerging patterns of the Victorian and UK interviews were analysed in their own context, before being contrasted with the relevant literature and all interview data, thus allowing for the responses to be explored individually, collectively, and comparatively, according to the participant's geographical location.

Due to the lack of access and visibility surrounding plea bargaining processes (this includes the absence of any existing administrative data on plea bargaining in Victoria), the use of interviews offered a mechanism to understand how plea bargaining operates in the Victorian and UK jurisdictions from the perspectives of those directly involved. While an analysis of only the court and/or internal prosecution policies that direct legal conduct may have provided a potentially easier method of obtaining data for a researcher from outside the legal community, it would not have provided sufficient detail of how plea bargaining works in practice. Instead, the use of interviews allowed for the investigation of how individuals interpret plea bargaining policy, and offered a way to capture the variation between what should happen (for example, expressed in internal prosecution policy) and what actually happens in practice. The interview data thus allows this discussion to move from opinions and statements of law and policy to determinations of what happens in practice.

It is important to note that the arguments in this article are informed largely by the perspectives of Victorian legal participants. However this does not reduce the relevance of the findings or the article's comparative nature. While the smaller number of UK participants may mean that some aspects or intricacies of the operation of the UK criminal justice process may be overlooked, the strong focus on the interview data obtained from the UK participants, combined with the voices of the Australian legal participants, enables a unique analysis of the Guidelines. Furthermore, all participants were asked to reflect upon whether their views were indicative or representative of the group, agency and/or body they represented. Overwhelming, the participants believed that their views were reflective of those of their colleagues, and others within the legal field, and not necessarily from their specified group. For example, prosecutors considered that they were speaking on behalf of defence practitioners or members of the judiciary. Thus there is a basis for claiming that the voices represented in this article are reflective of a more general UK-based perspective. The potential limitation caused by the smaller number of UK participants is also compensated for by reference to wider 
research findings within the field, particularly research examining the practice of discretion and plea bargaining in the UK.

\section{CONTROLLING Discretion}

The rule of law is often equated with structure, control and consistency - the need to treat like cases in a similar fashion. Discretion however, is considered 'the freedom to break rules', ${ }^{11}$ as Aas observes, 'discretion is usually regarded as the opposite of rules and law ... where, instead of deciding a question by recourse or fixed rule ... there is no prescribed ... course of action'.12 Discretion is the 'situation in which an official has latitude to make authoritative choices not necessarily specified within the source of authority which governs his decision making'. ${ }^{13}$ In effect, then, it directly contrasts with the common law aims of consistency, certainty and equality, insofar as it allows for individual prejudices and biases to control aspects of proceedings.

Discretion may therefore be described as 'the antithesis of a decision taken in accordance with the rule of law'. ${ }^{14}$ As Tata explores in his critique of binary legal dichotomies in the UK context:

the dichotomy between discretion and rules is apparent in both the traditions of legal-rational scholarship and the new penology. Both traditions rely on an understanding... of two basic and competing ways: discretionary or ordered rules. ${ }^{15}$

In reference to judicial decision-making, Tata further observes that traditionally the division between discretion and structured rules has meant that such powers are understood as 'either informal and thus essentially lacking in structure, arbitrary and capricious, or ... [appropriately] governed by legal rules, principles and policies'. ${ }^{16}$ As a result of this conflict, stringent controls regulating discretion have emerged within criminal justice systems, these impacting largely on the discretionary powers of judicial officers and

\footnotetext{
${ }^{11}$ Albert Frederick Wilcox, The Decision to Prosecute (Butterworths, 1972) 112.

${ }^{12}$ Aas, above n 2, 15.

${ }^{13}$ Burton Atkins and Mark Pogrebin, 'Discretionary Decision-Making in the Administration of Justice', in Burton Atkins and Mark Pogrebin (eds), The Invisible Justice System: Discretion and the Law (Anderson Publishing, $2^{\text {nd }}$ edn, 1982) 3.

${ }^{14}$ Davis, above $\mathrm{n} 2,25$.

15 Tata, above n 7, 429.

16 Ibid.
} 
prosecutors, with the justification that their public interest roles require control to give transparency and consistency to decisions. ${ }^{17}$

The move towards formally controlling discretion has arisen partially in response to a bureaucratic desire to improve accountability, and partially due to public perceptions that regulatory controls minimise abuses of power. ${ }^{18}$ Controlling discretion has also been supported on the basis that laws and formal restrictions are the framework of a 'democratic' justice system, offering consistency and uniformity. ${ }^{19}$ Monitoring discretion means all individuals are, at least in theory, treated under the same set of rules and receive like treatment. ${ }^{20}$ Controls have also emerged on the premise that it is usually the powerful and dominant classes who attain and gain from discretion, while the less powerful classes suffer. ${ }^{21}$ Therefore, reform in areas where there is the potential for individual or institutional abuse is promoted. As Pinkele claims:

The behaviour of no-one in a position of authority can be excluded from another's scrutiny... Decision makers should be allowed little other than the most minimal form of weak discretion ... The more constraints in place to

${ }^{17}$ Aas, above n 2; Roger Cotterrell, 'Law in Social Theory and Social Theory in the Study of Law', in Austin Sarat (ed), The Blackwell Companion to Law and Society (Blackwell Publishing, 2004) 21; Davis, above n 2; Kagan, above n 2, 212; Main Street Criminal Procedure Committee, 'Report on Backlog in Vancouver Adult Criminal Court' (Report, Provincial Court of British Colombia, January 2005); Carl F Pinkele, 'Discretion Fits Democracy: An Advocate's Argument', in Carl F Pinkele and William C Louthan (eds), Discretion, Justice and Democracy: A Public Policy Perspective (Iowa State University Press, 1985); Elaine Samuel and Ian Clark, 'Improving Practice: A Summary of Responses to the Consultation on the 2002 Review of the Practices and Procedure of the High Court of Justiciary' (Scottish Executive Research Council, 2003) <http://www.scotcourts. gov.uk/bonomy/docs/ConsultationAnalysis.pdf>.

${ }^{18}$ Charles D Breitel, 'Controls in Criminal Law Enforcement' (1960) 27(3) University of Chicago Law Review 427; Cotterrell, above n 17, 21; Kagan, above n 2, 212; William C Louthan, 'The Politics of Discretionary Justice Among Criminal Justice Agencies' in Carl F Pinkele and William C Louthan (eds), Discretion, Justice and Democracy: A Public Policy Perspective (Iowa State University Press, 1985); Samuel Walker, Taming the System: The Control of Discretion in Criminal Justice 1950 - 1990 (Oxford University Press, 1993).

${ }^{19}$ Aas, above n 2; Pinkele, above n 17; Walker, above n 18.

${ }^{20}$ Aas, above $\mathrm{n} 2$.

${ }^{21}$ Anthony Giddens, The Consequences of Modernity (Stanford University Press, 1990). For a broader discussion on the implications of discretionary decisions on minority communities, see Ben Bowling and Coretta Phillips, 'Disproportionate and Discriminatory: Reviewing the Evidence on Police Stop and Search' (2007) 70(6) Modern Law Review 936 and Darren Ellis, 'Stop and Search: Disproportionality, Discretion and Generalisations' (2010) 83(3) Police Journal 199. 
restrict discretionary administrative interpretation and implementation, the better off we are as democratic people. ${ }^{22}$

Accordingly, there has been a shift away from instinctive and intuitive judgments towards an expansion of policies, so that 'written rules replace custom ... and specialists administer the justice bureaucracy in accordance with written procedures and regulations'. ${ }^{23}$ This has been achieved through the use of statutory and formal requirements, and the creation of oversight and advisory bodies, such as the Sentencing Advisory Council in Victoria, or the Sentencing Council in the UK. The role of the Sentencing Council specifically entails preparing and monitoring sentencing guidelines to

ensure that courts across England and Wales are consistent in their approach to sentencing ... and to help judges and magistrates decide the appropriate sentence ... and allow for greater transparency in sentencing ... [by providing] a structured approach to determining the appropriate sentence. ${ }^{24}$

Aas suggests that the role of the Sentencing Council (then the Sentencing Guidelines Council) extends to include control over the exercise of judicial discretion in order to make 'decision-making more transparent and predictable ... [because] sentencing decisions lacked a coherent structure, they were a law without order'. ${ }^{25}$

This shift towards the control of discretion was also noted by participants from both the defence and prosecutor groups in the author's research, who observed that criminal proceedings in Australia are becoming increasingly bureaucratised, with greater controls placed on discretion. Defence A observed that 'it is the spirit of the times, the flavour of the month to formalise everything and control everything. Nothing is left to discretion, it is all regulation and structure'. Prosecutor E also maintained that 'in all areas, prosecutors, defence [practitioners] and the courts are trusted less and less, and monitored and checked more and more'.

\footnotetext{
${ }^{22}$ Pinkele, above $\mathrm{n} 17,560$.

${ }^{23}$ Louthan, above $\mathrm{n} 18,15$.

24 United Kingdom Sentencing Council, Sentencing Guidelines (2010) $<\mathrm{http}: / / \mathrm{www}$. sentencingcouncil.org.uk/sentencing-guidelines.htm $>$. See also, Code for Crown Prosecutors 2004 (UK); Code of Practice for Victims of Crime 2004 (UK); Farquharson Guidelines -The Role and Responsibility of the Prosecution Advocate 2002 (UK); Breach of Anti-Social Behaviour Order - Definitive Guideline 2008 (UK); Causing Death by Driving - Definitive Guideline 2008 (UK); Theft and Burglary in a Building other than a Dwelling - Definitive Guideline 2008 (UK).

${ }^{25}$ Aas, above n 2, 15.
} 
The implementation of legislative controls on the previously informal sentence indication hearings operating in Victoria's Magistrates' Court provides an example of this. Despite 30 participants claiming that this process operated effectively in its informal state, statutory guidance was enacted in July 2008 to formally dictate the required roles of those involved in summary sentence indication hearings, in order to provide transparency, consistency and control to the process. ${ }^{26} \mathrm{~A}$ further example can be seen in the recent changes in Western Australia, restricting the discretion of judges in sentencing cases where public officers, such as police members, paramedics or prison guards, are assaulted in the course of carrying out their professional duties. In such cases, discretion is restricted, as judicial officers must impose a minimum six-month jail term on adult offenders. ${ }^{27}$

\section{Comparing Plea Bargaining and Prosecutorial DISCRETION: UK AND AUSTRALIA}

Prosecutors, in addition to possessing the discretionary powers to decide whether or not to proceed with a case, also have discretion to decide how to prosecute, with which offence(s) they will proceed, whether they will accept or make a plea bargain offer, and whether to dismiss charges, all of which occurs without significant judicial oversight or review. Krauss refers to this power as 'prosecutorial adjudication' ${ }^{28}$ a process in which the prosecutor:

Serves as the central adjudicator of facts (as well as replacing the judge as arbiter of most legal issues) ..., evaluates culpability and chooses the charge for which he will accept a guilty plea ... [and offers] an advisory sentencing guideline ... [resulting in] the exercise of prosecutorial discretion affect[ing] almost every step of the criminal justice process, from charging to sentencing. ${ }^{29}$

Across western criminal jurisdictions, increases in the number of matters commencing each year has unsurprisingly led to prosecutors facing heavier

\footnotetext{
${ }^{26}$ Asher Flynn, 'Sentence Indications for Indictable Offences: Increasing Court Efficiency at the Expense of Justice? A Response to the Victorian Legislation' (2009) 42(2) Australian and New Zealand Journal of Criminology 244; Sentencing Advisory Council, 'Sentence Indication and Specified Sentence Discounts (Final Report, September 2007). See also, Criminal Procedure Act 2009 (Vic) s 61, formally governed by the Magistrates' Court Act 1989 (Vic) s 50A.

${ }^{27}$ Criminal Code Act Compilation Act 1913 (WA) s 318 (4)(b).

${ }^{28}$ Rebecca Krauss, 'The Theory of Prosecutorial Discretion in Federal Law: Origins and Development' (2009) 6(1) Seton Hall Circuit Review 1, 8.

${ }^{29}$ Ibid.
} 
workloads, often without the necessary resources to see every case through to trial. ${ }^{30}$ As a consequence, the discretionary powers of the prosecutor to make and accept an offer that results in an accused pleading guilty without the need for a contested trial, in other words, a plea bargain, has taken on a more prominent and arguably more significant role in the delivery of modern justice.

Plea bargaining is essentially a discussion between the prosecutor and the relevant defence practitioner regarding the accused person's likely plea, the possibility of negotiating the charge(s) and/or case facts, and the Crown's possible sentencing submission. The primary aim of discussions is to arrive at a mutually acceptable agreement, according to which the accused pleads guilty. This process is generally undertaken on the basis that it will enhance court efficiency by saving resource and financial expenditure, reduce court backlogs and prosecutorial workloads, and spare accused persons and victims prolonged proceedings. As Krauss observes:

Today, plea-bargaining and prosecutorial discretion determine the outcome of the vast majority of criminal cases. The prosecutor evaluates evidence and determines culpability in a process that is governed by very few legal standards. In doing so he exercises broad discretionary powers ... [which] would, in practice, be very difficult for a court to review. ${ }^{31}$

As a result, prosecutors have become what Bibas refers to as 'the key gatekeepers who ration criminal justice'. ${ }^{32}$

\section{The United Kingdom}

Plea bargaining is not a new phenomenon in the UK, with research suggesting that it has been a longstanding mechanism used to advance early guilty pleas since, at least, the early 1960s. This is despite the comments of Lord Scarman in $R v$ Atkinson $^{33}$ that 'plea bargaining has no place in the English criminal law'. ${ }^{34}$ The first significant guidance relating to plea bargaining, outside its

\footnotetext{
${ }^{30}$ For a discussion of the impacts of limited resources on prosecutorial discretionary decisionmaking in plea bargaining, see Asher Flynn and Kate Fitz-Gibbon, 'The Honeymoon Killer: Plea Bargaining and Intimate Femicide - A Response to R v Watson' (2010) 35(4) Alternative Law Journal 203.

${ }^{31}$, Krauss, above n $28,9$.

${ }^{32}$ Stephanos Bibas, 'The Need for Prosecutorial Discretion' (2010) 19(2) Temple Political and Civil Rights Law Review 369.

${ }^{33}$ [1978] 1 WLR 425.

${ }^{34} R$ v Atkinson [1978] 1 WLR 425, 462. See also, John Baldwin and Mike McConville, Negotiated Justice: Pressures to Plead Guilty (Martin Robertson, 1977); Duncan Watson,
} 
condemnation in Atkinson, was provided in $R v$ Turner. ${ }^{35}$ However this case focused on the role of sentence indications, whereby a judge informs the accused or their representative of the possible sentence they would receive should a guilty plea be entered, as opposed to the plea discussions that occur between the prosecution and defence practitioner. It was not until the 2000s that controls restricting prosecutorial discretion in relation to charging decisions, the prosecutor's role in the sentencing hearing, and in plea bargaining discussions, became more clearly defined, largely by the Guidelines. Further to these Guidelines, Watson also notes that a 'cultural shift' towards greater acceptance of plea bargaining and early guilty plea incentives emerged in 2005, following the decision of $R v$ Goodyear. ${ }^{36}$ This case altered the previous guidelines established in Turner to allow accused persons to request an indication of the highest possible sentence type and range that could be imposed if they pleaded guilty. ${ }^{37}$

The Guidelines were initially introduced in December 2000, in accordance with the Human Rights Act 1998 (UK) section 7, which outlined the importance of transparency in the administration of justice. Advisor A (UK) observed that this version of the Guidelines was also implemented in response to a publicised case of prosecutorial misconduct, which, he stated, resulted in the

prosecutor becoming totally bound up in the sentencing proceedings, so much so that the Attorney General found that his hands were fettered when he wanted to refer the case for an unduly lenient sentence to the Court of Appeal.

In 2003, a comprehensive review of the Guidelines was undertaken to reflect the shifting role of the prosecution within the criminal justice process and revised guidelines were implemented in 2005, 'after about the fourteenth version was written ${ }^{38}$ In March 2009, the Guidelines were further amended to provide 'specific guidance on ... a uniform and workable procedure for plea negotiations between the prosecution and defence prior to trial, ${ }^{39}$ and

\footnotetext{
'The Attorney General's Guidelines on Plea Bargaining in Serious Fraud: Obtaining Guilty Pleas Fairly?' (2010) 74(1) Journal of Criminal Law 77.

35 [1970] 2 QB 321.

${ }^{36}$ [2005] EWCA Crim 888.

${ }^{37}$ Watson, above n $34,85$.

${ }^{38}$ Advisor C (UK).

${ }^{39}$ Watson, above $\mathrm{n} 34,78$.
} 
also, according to Advisor C, to 'provide additional control of a prosecutor's discretion ... beyond the limited scope of the original guidelines'. ${ }^{40}$

The Guidelines operate in conjunction with a number of other legislative and formal controls that regulate prosecutorial conduct and discretion in the UK, including the Farquharson Guidelines on the Role and Responsibility of the Prosecution Advocate 2002 (UK), which direct conduct within the prosecution process; the Code for Crown Prosecutors 2010 (UK), which controls conduct in relating to the laying of charges through to the Plea and Sentencing Hearing; the Code of Practice for Victims of Crime 2006 (UK), which outlines prosecutorial obligations to victims and is recognised in section 32 of the Domestic Violence, Crime and Victims Act 2004 (UK); and the Prosecutors' Pledge 2005 (UK). The key aims of the Guidelines are to make legal conduct transparent, and to uphold public interests, which is very much in keeping with the breadth of these other controls. As Advisor A (UK) explained:

Very much the driver of the Guidelines is you get the charge right, you get the acceptance of plea right and you play a part in the sentencing. Then you are, as a prosecutor, a more rounded individual. You're influencing in terms of public interest and in the public good.

Advisor D (UK) also maintained that a central aim of the Guidelines is to ensure that victims' rights are seen to be considered within plea bargaining and sentencing processes, which aligns strongly with the victim-focused approach of the UK justice system. ${ }^{41}$ Both the UK Government and Office of the Attorney General have been prominent advocates for recognising victims' rights in formal policies and legislation. ${ }^{42}$

The Guidelines are divided into five areas, outlining the required conduct and responsibilities of prosecutors in the acceptance of a plea bargain, and, where relevant, the responsibilities of judges and defence practitioners. Such responsibilities include identifying the main factors for consideration when deciding whether to plea bargain - for example, whether the plea bargain upholds public interests, establishes the severity of the offending behaviour,

\footnotetext{
${ }^{40}$ See Appendix A for a copy of the Guidelines.

${ }^{41}$ See s A1, ss B3-B5.

${ }^{42}$ Crown Prosecution Service, Code of Practice for Victims of Crime (at 3 April 2006); Crown Prosecution Service, Code for Crown Prosecutors (at 22 February 2010); Domestic Violence, Crime and Victims Act 2004 (UK) s 32; Crown Prosecution Service, Prosecutor's Pledge (at 21 October 2005) 2, 3. See also, Joanna Shapland, Jon Willmore and Peter Duff, Victims in the Criminal Justice System (Gower, 1985); Heather Strang, Repair or Revenge: Victims and Restorative Justice (Clarendon Press, 2002).
} 
reflects the victim's physical and/or emotional injuries, and demonstrates the crime's impact on the community and what the likely sentence might be. Instructions for both prosecution and defence counsel in determining the 'basis of the plea' (essentially the agreed summary of facts upon which the agreement is based and from which the court will sentence) are also outlined in section $\mathrm{C} 1$ of the Guidelines. Once this basis is determined, the Guidelines require that it be signed by all parties and lodged as part of the official court records, thereby ensuring the transparency of the charging decision.

While seeking to control discretion in plea bargaining, the Guidelines offer a compromise between flexibility and formal rules, in order to enable a seemingly transparent and equitable system that still allows cases to be considered according to their individual circumstances. The benefits of this type of control are noted by Bibas, who claims that

even in a world of unlimited resources and sane criminal codes, discretion would be essential to doing justice. Justice requires not only rules but also fine-grained moral evaluations and distinctions. ${ }^{43}$

Thus as Watson argues, 'the plea-bargaining system ... in England and Wales manages to avoid becoming an American-style pressure cooker by comparatively slight reductions in prosecutorial discretion'. ${ }^{44}$ It seeks to create a transparent, structured and accepting culture, whereby prosecutors use their discretion consistently and in line with the ideals of justice.

Although not incorporated in statute, the Guidelines are mandatory requirements for prosecutors and are endorsed by the courts as 'best practice'. ${ }^{45}$ This means that, while breaching the Guidelines would not in itself result in a case being dismissed, deviation could be a factor influencing an Appeal Court in ruling against the Crown. ${ }^{46}$ As Advisor A (UK) observed, 'they are guidelines, but they must be followed'. This system of control, as explored by Watson, enables the Guidelines to 'act as a safeguard against unregulated and occluded discussions that eschew fairness for the accused, by creating a wholly transparent procedure which stands up to judicial scrutiny'. ${ }^{47}$

\footnotetext{
${ }^{43}$ Bibas, above $\mathrm{n} 32,370$.

${ }^{44}$ Watson, above $\mathrm{n} 34,78$.

${ }^{45}$ Advisor C (UK).

${ }^{46}$ Ibid.

${ }^{47}$ Watson, above n 34, 90.
} 


\section{$2 \quad$ Australia}

In contrast, Victoria's plea bargaining system allows cases to be resolved on the basis of unscrutinised prosecutorial decisions, in an unregulated, nontransparent process. In Victoria, no administrative data are kept, outlining when or why plea bargaining occurs or how often discussions result in guilty pleas. Importantly, plea bargaining itself is not recognised in, or controlled by, any Victorian statute. Thus, not only is the process itself not monitored in any statistical or formal sense, but there is also no legal acknowledgement of the process. Instead, plea-bargaining falls under the discretionary powers of the prosecution, which means that we rely solely upon those who engage in discussions to ensure that the process, and resulting agreements, uphold the same principles of justice - for example, consistency, accessibility, equality and fairness - which apply to more transparent proceedings, such as the trial. This is particularly concerning given that agreements can alter the seriousness of the conviction and sentence imposed on an accused, and can remove the opportunity for the victim to provide testimony or for the prosecution to prove its case within the confines of the contested trial and the rules of procedure applied within it. ${ }^{48}$

Within the Victorian Office of Public Prosecutions, three internal policies provide some guidance to prosecutors when plea bargaining. For example, Prosecutorial Discretion Policy 2 encourages them to initiate discussions with the defence practitioner, regardless of whether the defence approaches them, and to refrain from offering deals to accused persons who are not legally represented. ${ }^{49}$ Significantly, however, OPP internal policies are not legally binding and there are no mechanisms in place to monitor whether prosecutors adhere to them. For this reason they ultimately impose limited accountability or control on the plea bargaining process or the conduct of those involved, and they do little to provide the process or its outcomes with any level of public legitimacy.

The private nature of plea bargaining and the lack of control over this aspect of prosecutorial discretion is quite unusual, given the increasing shift in Victoria towards greater transparency and control of discretion in proceedings that impact on sentencing. For example, we have seen the introduction of sections 61 and 208-209 of the Criminal Procedure Act 2009 (Vic), which allow judicial sentence indications to operate within both the summary and

\footnotetext{
${ }^{48}$ Asher Flynn, 'Non-Transparent Justice and the Plea Bargaining Process in Victoria' in Marie Segrave (ed), Australian and New Zealand Critical Criminology Conference Proceedings 2009 (Australian and New Zealand Critical Criminology Network, 2009).

${ }^{49}$ Office of Public Prosecutions, Prosecutorial Discretion Policy 2 (at 14 February 2008).
} 
indictable criminal jurisdictions. Section 6AAA of the Sentencing Act 1991 (Vic) has also been introduced to clarify the sentence discount applied in exchange for an accused person's guilty plea. The absence of control over plea bargaining is also unusual, given the shift towards restricting judicial sentencing powers. This shift, Aas claims, 'makes the pre-trial decisions, where the charges are negotiated, more significant, ${ }^{50}$ because the inflexibility of set penalties and minimum sentences means that the charging decision has a greater impact on the accused person's likely sentence. This argument increases the justification for providing some control over the prosecutorial discretion to make alterations to an accused person's charges initially, especially given the Victorian State Government's proposal to introduce mandatory minimum sentences for serious offences. ${ }^{51}$

\section{Problems With Victoria's Plea Bargaining PROCESS}

\section{$1 \quad$ Pressures on Accused Persons}

The need to restrict the unscrutinised discretionary powers of the prosecution has been a common theme identified in research for several decades. In the late 1960s Davis pertinently asked the question: 'why should the prosecutor's charging decision be immune to review by other officials and immune to review by the courts, even though our legal and governmental system elsewhere generally assumes the need for checking human frailty?'. ${ }^{52}$ When interview participants were asked to respond to this same question in the context of Victoria's plea bargaining process, an emerging theme in their perspectives was that retaining an absence of control on prosecutorial discretion in plea bargaining was necessary, due to the inherent tension that exists between flexibility and uniformity. Participants claimed that some prosecutorial discretion is required to facilitate reasonable outcomes and to

\footnotetext{
${ }^{50}$ Aas, above n 2, 19.

${ }^{51}$ Galligan, above n 3; Sidney I Lezak and Maureen Leonard, 'The Prosecutor's Discretion: Out of the Closet-Not Out of Control', in Carl F Pinkele and William C Louthan (eds), Discretion, Justice and Democracy: A Public Policy Perspective (Iowa State University Press, 1985). See also, The Nationals for Regional Victoria, Coalition Government to Set Minimum Sentence Standards for Serious Crime (23 November 2010) < http://www.vicnats. com/news/article. a spx?ID=11590>.

${ }^{52}$ Davis, above n 2,81 .
} 
consider each case's individual circumstances - a theme referred to as 'to turn on the facts' ${ }^{53}$ or the 'factual matrix'. ${ }^{54}$

But a problem arises from this ideal because, without some uniformity, the flexible, unscrutinised powers of prosecutors have the potential to be abused, or, perhaps more prominently, create a perception of unfairness or abuse, which impacts on public confidence in the process. ${ }^{55}$ As Bibas rightly observes, 'discretion is bad only when it becomes idiosyncratic, unaccountable, or opaque'. ${ }^{56}$ These are all terms which could be used to describe the current system of plea bargaining in Victoria.

The private nature of the plea bargaining process that currently operates in Victoria means that transparent outcomes are seemingly absent. For this reason there is a level of attractiveness in ensuring that the exercise of prosecutorial discretion in plea bargaining is transparent and subject to greater scrutiny. This is particularly so if this is also likely to alleviate some of the main concerns arising from plea bargaining's non-transparency, such as the perceived pressures that exist on both the prosecution and the accused to make and accept plea bargaining deals.

One of plea bargaining's primary weaknesses is its potential to create pressures compelling accused persons to plead guilty. These pressures are heightened by the secrecy surrounding plea bargaining in Victoria, because there is no scrutiny applied to the process, the prosecutor's decision, or the resulting agreement. As Watson argues, 'the danger is that an unregulated or poorly designed [plea bargaining] system will lead to excessive or otherwise improper pressure being applied to the defendant, resulting in an unacceptable risk of the innocent pleading guilty'. ${ }^{57} \mathrm{~A}$ similar argument emerged in Baldwin and McConville's analysis of plea bargaining in the UK, prior to the implementation of the Guidelines. In this analysis they claimed that:

The guilty plea system transforms criminal justice from one which seeks to determine whether the State has reliably sustained its burden of proof to another which seeks to determine whether the defendant, irrespective of guilt or innocence, is able to resist the pressure to plead. ${ }^{58}$

\footnotetext{
${ }^{53}$ Prosecutor $\mathrm{H}$.

${ }^{54}$ Defence C.

${ }^{55}$ Flynn, above $\mathrm{n} 48$.

${ }^{56}$ Bibas, above n 32, 372.

${ }^{57}$ Watson, above $\mathrm{n} 34,79$.

${ }^{58}$ Baldwin and McConville, above $\mathrm{n} 34$, vi.
} 
Pleading pressures on the accused can emanate from a multitude of factors, including limitations on the availability of Legal Aid funding, ${ }^{59}$ or the general financial constraints of a trial. These can appear particularly burdensome when contrasted with plea bargaining's benefits: for example, a reduction in the severity of the original charges laid. As Defence C explained:

Some defendants just can't face the thought of going to a contested hearing because of the stress and emotional trauma. More significantly though, most can't afford the cost ... so there is a fair bit of pressure on them just to plead guilty, especially when it is sweetened with a bargain.

Pleading pressures can also be increased by the possibly significant reduction in the sentence length and type given in exchange for a guilty plea. ${ }^{60}$ As an accused person in Baldwin and McConville's research claimed, 'if your barrister comes up to you and tells you you've got a 50-50 chance that if you plead guilty you'll get off with less than if you plead innocent, well what would you do? ${ }^{, 61}$ Defence A similarly identified this concern:

The defendant obviously has more to lose than the Crown, particularly if it may involve a jail term. There is of course a natural pressure because if you go on with the trial and lose, there are bigger consequences. If you don't settle you may get an acquittal, but it is unknown. It is a gamble either way, and unpredictable. So there is pressure on them to plead.

Such pressures are particularly concerning given the number of vulnerable people who come before the law. ${ }^{62}$ As Advisor B explained:

There are such a high proportion of people who will go through the system who weren't functioning very well at the time they committed the crime and are not functioning any better by the time the case gets to court, and for that kind of client, pressure to plead is a real issue.

Prosecutor $\mathrm{H}$ also identified these vulnerabilities, arguing that 'in the justice system, you are often dealing with people who have substance abuse problems or psychological or psychiatric problems, or other pressures which they are

\footnotetext{
${ }^{59}$ Asher Flynn, 'Victoria's Legal Aid Funding Structure: Hindering the Ideals Inherent to the Pre-Trial Process' (2010) 34 Criminal Law Journal 48; Frank Stephen and Cyrus Tata, 'Impact of the Introduction of Fixed Payments into Summary Criminal Legal Aid: Report of an Independent Study' (Report, Scottish Executive, 2007) <http://www.scotland. gov.uk/Resource/Doc/180464/0051284.pdf?.

${ }^{60}$ Defence A. See also, Sentencing Act 1991 (Vic) s 5(2)(e).

${ }^{61}$ Baldwin and McConville, above n 34, 26.

${ }^{62}$ Peter Underwood, 'The Trial Process: Does One Size Fit All?'(2005) 15 Journal of Judicial Administration 165 .
} 
ill-equipped to deal with'. The essence of such concerns is reflected in Mack and Roach Anleu's Australian-based research, which suggested that those most likely to plead guilty are indigenous people, and accused persons who would 'not present well in court'. ${ }^{63}$

When discussing the potential for the unscrutinised plea bargaining process to exacerbate pleading pressures, eight Victorian participants (exclusively prosecutors) argued that this was unlikely. Prosecutor A stated

an innocent accused is never going to plead guilty. I think the pressure probably is on them and that is there to get them to plead early, to get the [sentence] discount ... but if you are an accused and you are totally innocent, you are never going to plead.

Prosecutor L similarly maintained, 'we don't get too many cases of innocent people pleading guilty. We don't'.

While these participants acknowledged that plea bargaining has the potential to place some pressure on an accused person, simply due to the possible concessions inherent to such agreements, all eight maintained that this pressure was not 'inappropriate' (Prosecutor C), even despite plea bargaining's private nature which can work to mask the existence of any pressures, or at least create the perception of a mask. As Prosecutor C claimed, 'there is an uncertainty in the whole process ... So that uncertainty is probably more a factor as to why a defendant might plead, but it is not an unreasonable pressure ... It is not unreasonable. It is not going to force an innocent person to plead'. Following a similar line of argument, Prosecutor $\mathrm{H}$ explained:

I have no doubt that defendants would feel, on occasions, a degree of pressure when making a pleading decision. But plea bargaining doesn't create unacceptable pressure. I suppose it is a question of whether plea bargaining affects a genuine and informed decision being made that is the issue.

Although denying the negative consequences of pleading pressures, in both comments the participants refer to either an 'unreasonable' or 'unacceptable' pressure, which demonstrates that they recognise there is some degree of pressure applied to accused persons during plea bargaining. However, in their

${ }^{63}$ Kathy Mack and Sharyn Roach Anleu, 'Choice, Consent and Autonomy in a Guilty Plea System' (2000) 17(1) Law in Context 82. See also, Chris Cunneen and Melanie Schwartz, 'Funding Aboriginal and Torres Strait Islander Legal Services: Issues of Equity and Access' (2008) 32(1) Criminal Law Journal 38. 
opinion, these pressures exist at a 'reasonable' and 'acceptable' level. These claims have a significantly different meaning to a statement indicating that no pressures are applied, and ultimately raise concerns as to how one determines when these 'reasonable' and 'appropriate' pressures become 'unreasonable' or 'inappropriate' pressures, particularly given the non-transparent and unscrutinised use of plea bargaining by prosecutors in Victoria.

Of these eight prosecutorial participants, six pointed to legal representation as a safeguard for accused persons, as opposed to favouring greater control of prosecutorial discretion in line with the UK Guidelines. After all, as Stephen, Fazio and Tata maintain, "such bargains are not between "efficient prosecutors" and defendants, but effectively between prosecutors and defendants' lawyers' ${ }^{64}$ Prosecutor $M$ claimed, 'it is not in a defence solicitor's interest to have their client plead to something which is either not appropriate or against the interests of their client. So I can't see how defendants could feel pressured to plead guilty'. Nine (of 11) defence participants also identified legal representation as a factor reducing pleading pressures. These views were based largely on the argument expressed by Defence E, that 'the defence provides quality advice about the offer and that helps the accused make a principled, informed and appropriate [pleading] decision'.

The extent to which legal representation alone offers a safeguard to protect accused persons from pressures, without the added safeguard of more transparent regulations on prosecutorial discretion - such as requiring any plea bargaining decisions be reviewed by a superior prosecutor - was, however, questioned by six participants ( $n=4$ Victorian, $n=2 U K$ ), including Prosecutor S, who claimed:

The obligation is on the defence representatives to make sure, as much as they can, that they minimise the pressure on their client and I am sure they do that to an extent. But at the end of the day, that client may well be looking at the potential difference between going into custody and serving an actual term of imprisonment or not, depending on whether or not they plead guilty ... or it might affect, to a significant extent, the deal they get, so the representative can't really guard against that.

Prosecutor W (UK) similarly maintained that 'yes, they feel pressured with representation, more so without, but they still feel pressure to plead. If they

\footnotetext{
${ }^{64}$ Frank Stephen, Giorgio Fazio and Cyrus Tata, 'Incentives, Criminal Defence Lawyers and Plea Bargaining' (2008) 28(3) International Review of Law and Economics 212, 212.
} 
are likely to get a good plea offer or have monetary constraints, they just want to get it out of the way with as few hearings as possible'.

Australian and UK research also recognises the possibility that legal representation can have limited effect in protecting an accused person against pleading pressures and that it can potentially enhance such pressures. ${ }^{65}$ This is due to the obligation on legal representatives to instruct 'on the strength of the prosecution case and the dangers of pursuing a weak defence', 66 which Freiberg and Seifman suggest may 'inadvertently be providing some inducement to the accused to plead guilty'. ${ }^{67}$ Thus, "when [a legal representative informs] a client they risk a heavier sentence [if they do not plead guilty] ... defendants are likely to be substantially influenced in deciding how to plead'. ${ }^{68}$ For this reason, a legal representative's role in safeguarding accused persons from pleading pressures can be somewhat diminished, particularly when dealing with vulnerable or disadvantaged individuals. ${ }^{69}$

Advisor B similarly argued that legal representation does not safeguard the accused by minimising pleading pressures, particularly in Legal Aid cases. He claimed that:

Often legal representation is decided on the day of the hearing. So you don't have a lot of meetings with your lawyer necessarily prior to the day ... The courts take the view that if people are represented that is the ultimate safeguard. But when you don't meet your lawyer until the day of the hearing, well I don't know how good that [protection] is.

This view is supported by McConville and others, whose observations of defence practitioners over 198 weeks in the UK found that 'solicitors had little personal contact with clients, even at court'. ${ }^{70}$ These problems are exacerbated by the fact that guilty pleas are 'regarded as the highest form of proof ... [the] equivalent to a conviction after a trial', ${ }^{71}$ which means that

${ }^{65}$ Robert D Seifman and Arie Freiburg, 'Plea Bargaining in Victoria: The Role of Counsel' (2001) 25(2) Criminal Law Journal 64; JUSTICE, Negotiated Justice: A Closer Look at the Implications of Plea Bargains (JUSTICE, 1993).

${ }^{66}$ JUSTICE, above n 65, 11.

${ }^{67}$ Freiberg and Seifman, above n 65, 64.

${ }^{68}$ Ibid.

${ }^{69}$ Mack and Roach Anleu, above n 63, 75.

${ }^{70}$ McConville et al, Standing Accused: The Organisation and Practices of Criminal Defence Lawyers in Britain (Clarendon Press, 1994) 167.

${ }^{71}$ Mike McConville, 'Plea Bargaining', in Mike McConville and Geoffrey Wilson (eds), The Handbook of the Criminal Justice Process (Oxford University Press, 2002) 355. 
'following the guilty plea, the only concern of the court is to decide upon the appropriate sentence' ${ }^{72}$ Little, if any, consideration is given to the potential pressures that led to the plea. As Skelton and Frank assert, 'the assumption that coercion disappears once there is consent ... is dangerous and denies the nuances relating to power that are present in all human interactions' ${ }^{73}$

The mere perception that plea bargaining's private nature may contribute to pleading pressures, particularly for vulnerable accused persons, constitutes a significant justification for ensuring greater transparency and accountability in the exercise of prosecutorial discretion. This could be achieved by implementing a more structured and transparent process, and requiring reviews of prosecutorial discretion in plea bargaining, in the way that the UK Guidelines do. As Prosecutor B claimed:

Unduly vulnerable people plead guilty. So there has [sic] to be safeguards and checks and balances more than just the legal representation to ensure that when a plea is entered based on a plea agreement, it is a true plea and is reflective of the defendant's wish to admit the offence.

Nineteen Victorian participants supported this justification for implementing similar Guidelines in Victoria, on the basis that it would assist in reducing misperceptions about plea bargaining, and assist in ensuring greater accountability in the process ( $\mathrm{n}=$ nine defence; $\mathrm{n}=$ two judiciary; $\mathrm{n}=$ =five prosecutor; $\mathrm{n}=$ three advisors).

\section{Resource Pressures on Prosecutors}

Plea bargaining's private nature can also exacerbate a perception that discussions are used simply to reduce resource expenditure, enhance clearance rates and alleviate court backlogs. In most common law systems, prosecutors face pressures to uphold public interests and respond to court delays by obtaining convictions in a timely manner. ${ }^{74}$ As a result, workload pressures exist which encourage prosecutors to engage in plea bargaining. As Prosecutor V (UK) maintained, 'there is pressure from the courts to resolve cases as quickly as we can because it gets it out of the court system'. Defence $\mathrm{K}$ similarly claimed that, because the benefits of plea bargaining are significant,

\footnotetext{
${ }^{72}$ Ibid.

${ }^{73}$ Ann Skelton and Cheryl Frank, 'How Does Restorative Justice Address Human Rights and Due Process Issues?' in Howard Zehr and Barb Toews (eds), Critical Issues in Restorative Justice (Willan Publishing, 2004) 208.

${ }^{74}$ See, eg, Public Prosecutions Act 1994 (Vic) s 24(C).
} 
[s]ometimes there is not necessarily pressure, but there are advantages to the prosecution accepting something less than they should because basically it cuts down their workload. So if you have prosecutors who are overworked they may settle for something, just to clear their books.

Prosecutor I also stated that in addition to pressures from the courts, internal pressures are also applied:

There is always pressure. Too many cases, not enough resources, budgetary cuts from above. It sort of all comes down to can we get through all these cases and every now and again someone complains about the [court] backlog. There will always be that pressure, as well as the fact that if we can get a nice plea bargain, rather than run a two-day trial, there is incentive just from a work viewpoint.

Although identifying these pressures, most participants claimed that the pressures were not 'unreasonable' (32 out of 37 participants). Prosecutor C stated, 'the pressure on the prosecutor is not that great ... There is pressure, but it is not unwarranted in any way'. Similarly, Judiciary F identified the pressures as 'appropriate':

There are some pressures, but there is not an inappropriate amount of pressure, because prosecutors are experienced and competent and know where it is appropriate and acceptable to make some form of compromise, without sacrificing the justice of the case they are presenting on behalf of the community.

Despite such comments, a concern remains that the absence of control on prosecutorial discretion in plea bargaining could result in unjust or inappropriate outcomes due to efficiency pressures. At the very least, the absence of control helps fuel a perception that responding to court inefficiency is a primary motivating factor in the Crown's decision to plea bargain. In addition, like the arbitrary distinction made between 'reasonable' and 'unreasonable' pressures on accused persons, similar labels ('warranted' or 'appropriate') were applied to the degree of pressure facing prosecutors. These arbitrary labels further legitimate concerns as to how one determines when these pressures move from being 'warranted' to 'unwarranted', or from 'appropriate' to 'inappropriate', given the private nature of plea bargaining and the lack of scrutiny or transparency surrounding prosecutorial discretion in making charging decisions.

As a consequence of their non-transparency, there remains the possibility that discretionary plea bargaining decisions are based on idiosyncratic reasoning, such as a prosecutor's need to clear workloads. As Bibas maintains, in such 
situations 'we rightly fear that justice will vary from prosecutor to prosecutor, with each one a law unto himself and his own whims, biases, and shirking, ${ }^{75}$ The need to redress this 'fear' thus provides further justification for imposing more structured processes and requirements on prosecutorial discretion in plea bargaining, in line with the UK Guidelines.

\section{The Section C6 Requirements}

The overwhelming majority of Victorian participants (29 of 35) responded positively to the UK Guidelines, generally on the basis that they are 'just making an informal process visible really'. ${ }^{76}$ However, one section of the Guidelines was identified as moving beyond an acceptable level of control by significantly regulating and altering prosecutorial pre-trial preparation, while also, to some degree, restricting judicial independence in sentencing. These concerns relate to section C6 of the Guidelines introduced in June 2007 and the amendments to sections $\mathrm{C} 7$ and B5 in 2009. These sections are referred to as section $\mathrm{C} 6$ requirements within this article.

The original section C6 was implemented in response to the Lord Chief Justice's comments in $R v$ Cain ${ }^{77}$ where he criticised the lack of guidance presented to sentencing judges by prosecutors. Section C6 therefore obliged prosecutors to prepare a Plea and Sentence Document seven days prior to the Plea and Case Management Hearing in the Crown Court, regardless of whether there was a perceived likelihood of the accused pleading guilty. This document required prosecutors to commit to writing: the aggravating and mitigating factors; statutory provisions relevant to the accused or the offence(s); a Victim Personal Statement(s); evidence of any impact of the crime on the community; and applications for orders, such as a confiscation order. Prosecutors were then required to use this material to determine a qualitative and quantitative sentencing range - for example, a custodial sentence between three and five years - which would be acceptable from their perspective if the accused pleaded guilty at the hearing. ${ }^{78}$

\footnotetext{
${ }^{75}$ Bibas, above n 32, 371.

${ }^{76}$ Defence E.

${ }^{77}$ [2006] EWCA Crim 3233.

${ }^{78}$ Advisor C (UK).
} 
According to Advisor $\mathrm{C}$, the official purpose of the section $\mathrm{C} 6$ requirements is:

to further enhance the role of the prosecutor in the sentencing process by ensuring there is an accurate record of the basis on which a case is brought, and that the court has the necessary assistance in sentencing. ${ }^{79}$

Although the C6 requirements arguably achieve this end, most interview participants considered the actual justification of these requirements to be the likely pragmatic benefits. If the accused pleaded guilty, the prosecutor could address the court immediately and a sentence could be determined without adjournment and the risk of any further delay in the finalisation of the case. ${ }^{80}$ Accordingly, participants questioned whether the perceived 'efficiency' benefits of this mode of control exceeded the potentially negative consequences, particularly the possible impact on prosecutorial resource expenditure (41 of 46 participants). As Prosecutor L maintained, 'fortunately we in Victoria are not in that UK situation. We don't have the same imperatives or formalised restrictions on us to try and absorb delay to that extent'.

As a result of amendments in 2009, the section C6 requirements were reworded to reflect a less compulsory requirement on the prosecution to provide information. Thus section C6 now requires the completion of the document 'where it is likely to assist the court'; section B5 requires that prosecutors 'may offer assistance to the court by making submissions ... as to the appropriate sentencing range', and section $\mathrm{C} 7$ states that it 'remains open to the prosecutor to provide further [sentencing] information ... where he or she thought that likely to assist the court, or if the judge requests it'. The use of the terms 'may offer assistance' and 'where he or she thought that likely to assist the courts' implies a less restrictive requirement on the prosecutor to undertake these tasks. However, when questioned as to the impact of these linguistic changes on prosecutorial conduct, Advisor C (UK) maintained that:

Although the wording might've changed, the judges can still request the information, and they do. They still expect this information and they expect it to be ready early, so really prosecutors will still be expected to have a document outlining a sentence range and all relevant sentencing factors readily accessible pre-trial.

\footnotetext{
${ }^{79}$ Advisor C.

${ }^{80}$ Ibid.
} 
Based on this assessment, despite the 'voluntariness' aspect of the amended wording, the section C6 requirements still appear to be very much a 'requirement' of the prosecutor in the plea bargaining process.

\section{SiMILAR GUIDELINES IN VICTORIA?}

\section{$1 \quad$ Perceived Limitations of Similar Guidelines}

The section C6 requirements were not supported by any Victorian participant. In fact, the majority of Victorian prosecutorial (15 of 19) and defence (eight of 11) participants criticised the section C6 requirements for their potential to hinder plea bargaining. They believed the shifting of the prosecution's focus towards written advocacy and sentencing at an early stage of the criminal justice process is likely to reduce their ability and time to consider early resolutions. Prosecutor J claimed that

once you start to formalise such processes, it has a hampering impact on the whole notion of plea bargaining. It extends beyond the prosecutor's historical duty to the public and [the] court, and would in all likelihood hinder them from thinking about early resolutions.

Prosecutor C further stated that:

The more we seem to generate paperwork, the more we seem to spend on the paperwork rather than actually spending time analysing the case and trying to assess it. There has been a preoccupation with people having to file forms on time, and that's become the primary focus of everyone, and people don't talk anymore and you can't resolve things if you don't talk.

Another prominent problem surrounding the section C6 requirements, and identified by the participants, involved their potential to encroach upon judicial independence in sentencing. Judiciary E claimed, 'it is important that prosecutors understand that the court is independent of them, just as we must understand that their prosecuting decisions are independent of us'. Prosecutor D similarly maintained that:

It is not our role to provide that information. We can point out the authorities and the precedents and even suggest perhaps a rough custodial or non-custodial, but that should be it. Otherwise, you run the risk of hindering them from making a decision, because they know there will be a basis for a Crown appeal if it doesn't fit. 
In contrast to these views, two of the four UK prosecutor participants were supportive of the ideals behind the section C6 requirements, as Prosecutor T (UK) explained:

Sentencing is complex and a lot of erroneous sentences tend to be made which get to the Court of Appeal. To make sure the appropriate sentence is then passed, it is right that the prosecutors, with their public interest role, play a role in assisting the court to make sure the sentence is right.

This view was also reflected in the comments of the three UK policy advisors. As Advisor A (UK) claimed, 'in effect, what we are saying is that prosecutors always need to stand up to the mark in sentencing, which means they have to play a part in the sentencing process'. Similarly, Advisor C (UK) maintained that judicial independence is not hindered by a prosecutorial sentencing range because 'it is not determinative. The judge can still make a decision independent of their [prosecutor's] statement'. In addition, Advisor D (UK) argued that the prosecutor's involvement in sentencing is beneficial because it provides the judge with a framework to ensure their sentence corresponds with mandatory sentencing regulations:

Prosecutors are not advocating and will never advocate what the sentence should be. But what the Guidelines are saying is, on the basis of the defendant's offending, on the basis of $\mathrm{x}, \mathrm{y}$ and $\mathrm{z}$, the CPS are saying the appropriate sentencing range for this is between two and four years ...The court can say I thank you Mr Prosecutor but I think you are talking a bit of rubbish and I am going to sentence him to $\mathrm{x}$. But at least you have tried to assist the court in where the range should be ...We are also saying that you have a responsibility when you stand up as a member of the CPS to make sure the court enters a sentence that is good in law.

Further to the public interest and transparency justifications identified by the UK participants, the potential for the section C6 requirements to respond to court inefficiency levels, particularly delays in case finalisations, was also highlighted as a main benefit. Advisor C (UK) observed:

If the defendant doesn't plead guilty, they go to trial and if they get convicted, then you will still need it [the document]. And if they do plead guilty, you need it and you need it fairly urgently and you will have it. So it is not a case of the prosecution going to court and not being able to give the required information to the court because they didn't have time to complete it before the hearing. Because of this change, this information will be available straight away.

However, even as a supporter of the ideals behind the section C6 requirements, Advisor A (UK) acknowledged the potential limitations of 
preparing a sentence-focused document at such an early stage of the criminal justice process. In doing so, Advisor A indicated a potentially significant flaw in the effectiveness of the Guidelines to respond to court inefficiency levels:

This is where the world changes and it is going to increase workloads dramatically. I have had so much stick from prosecutors over this because it is going to create a lot of additional work and there is a lot of angst about it, because it requires prosecutors to prepare a fairly substantial document that is only useful for the sentencing process and it will often be prepared before any plea discussions take place, [or] the defendant makes a decision to plead.

As is implicit in Advisor A's (UK) claims, there are potentially quite significant resource consequences that arise from requiring that a sentencefocused document be compiled pre-trial. Preparation of the document requires prosecutors to undertake a substantial level of work which is generally not completed until after guilt is established at trial or by plea. These concerns were also acknowledged by the Victorian participants and two of the UK participants who opposed the requirements, with Prosecutor V (UK) maintaining,

there is [sic] already excessive workload pressures on prosecutors here in the UK where plea bargaining is very common, because the volume of work is so great and we couldn't get through it unless we resolved cases, and I imagine this pressure will only get worse with this.

Prosecutor $\mathrm{G}$ adopted a similar argument, claiming:

Prosecutors don't really have time to be completing sentencing information before a guilty plea [is entered] so you may find people turn up at the pretrial process and not have done all the correct forms and procedures. But you can't really blame them, because they are under other work pressures already.

A related problem identified by participants involved the likely expenditure of unnecessary resources, because the case is not guaranteed to be resolved by guilty plea or finding. In the period 1 July 2010-30 June 2011, across all Crown Courts in England and Wales, over 20 per cent of cases resulted in a dismissal or a not guilty verdict. ${ }^{81}$ There is thus a basis for supporting the argument that this early use of resources will be unnecessary in just over one-

\footnotetext{
${ }^{81}$ Ministry of Justice, 'Judicial and Court Statistics 2010' (Full Report, July 2011) 91 $<$ http://www.justice.gov.uk/downloads/publications/statistics-and-data/courts-and-sentencing/ judicial-court-stats.pdf $>$.
} 
fifth of matters. Furthermore, the participants identified that any efficiency benefits are only likely to be obtained if the accused pleads guilty at the pretrial stage. Given that between 2009 and 2010, late guilty pleas, which are pleas entered on or up to two days before the trial, were entered in over 26 per cent of cases across all Crown Courts in England and Wales, the likelihood of this benefit impacting significantly on court efficiency levels is questionable. ${ }^{82}$ In addition, as two Victorian participants identified, even if a guilty plea is entered pre-trial, the benefit of early prosecutorial preparation will only arise if the defence also has all plea materials prepared..$^{83}$ If they are not prepared, the hearing has to be adjourned, regardless of the level of preparation undertaken by the prosecutor.

In responding to such criticisms, Advisor C (UK) drew comparisons to a similar initiative operating in New Zealand, involving a Sentencing Memorandum. ${ }^{84} \mathrm{He}$ argued that, in comparison to the requirements of the New Zealand document, the section C6 requirements were a 'brief and easily prepared piece of work'. He explained:

Within s C6 there is a plea and sentence template, which is a one-page document. A Sentencing Memorandum is like a book that prosecutors have to complete. We think the Plea and Sentence Document will provide sufficient assistance to the court, without going down the path of the Sentencing Memorandum, which is an excellent document and would be great, but we don't have the capabilities to do it because we are dealing with a large volume of crime and it wouldn't be practical.

While there are similarities between the two documents-for example, both require the identification of any aggravating factors and, if applicable, any sentences imposed on co-offenders - there is a significant difference between them. The Sentencing Memorandum is completed only after a guilty plea or finding is returned, and must be filed with the court two days prior to the sentencing hearing, not during the pre-trial process. Comparisons between the documents can therefore be made based only on their content, not the timing or resource expenditure, as implied by Advisor C (UK). Advisor C's comments thus achieve little in the way of minimising the concerns surrounding the unnecessary early expenditure of prosecutorial resources, and they do not provide much justification for Victoria implementing like Guidelines.

\footnotetext{
${ }^{82}$ Ibid 107. Late guilty pleas were the reason for 63 per cent of the cracked cases across all Crown Courts in England and Wales between 2009 and 2010.

${ }^{83}$ Defence F; Prosecutor J.

${ }^{84}$ Sentencing Practice Note 2003 (NZ) s 2.
} 
In addition to the potential resource implications, Victorian participants raised doubts over the accuracy of a sentence-focused document prepared pre-trial. Interestingly, this issue was not identified by the UK participants opposed to the requirements, nor was it considered a significant limitation by those in support of the requirements. As Advisor D (UK) claimed, 'that is not really of great concern, because it can be fixed later'. When questioned about the impact of an inaccurate document being presented to the judge, Advisor D (UK) maintained that, "the judge can make a valuation of whether the document is reflective or not, and the document can also be changed before the actual hearing'. Upon further questioning about the resource implications of prosecutors having to make last-minute changes to ensure the document's accuracy, he claimed 'well, it's still not that damaging', and relied heavily on the argument that the prosecutor's recommendations were not a mandatory restriction on the judge's ultimate sentencing decision, so their 'impact can be minimal'. This is an interesting statement, given that it could be interpreted to mean that the purpose for introducing the section $\mathrm{C} 6$ requirements originally (to allow a sentence to be imposed at the pre-trial hearing immediately after a guilty plea is entered) becomes somewhat superfluous, and it highlights yet another prominent limitation of this section of the Guidelines.

The accuracy of a sentence-focused document prepared pre-trial was a strong concern for Victorian participants, and especially its accuracy in relation to accused persons. This was because many of their personal mitigating and aggravating factors, including their circumstances at the time of offending, their psychiatric or intellectual problems, their drug addictions, their future prospects and their 'response to the offence and prosecution (eg remorse, acts of reparation) ${ }^{, 85}$ may be unknown to the Crown at an early stage. This is particularly significant in light of a recent UK study, which found that personal mitigating and aggravating factors are prominent considerations for judges prior to determining a sentence - so much so that not only can they impact on sentence length, but they are also a key factor considered in deciding between a custodial or non-custodial sanction. ${ }^{86}$ For example, if at the plea hearing the accused person failed to address the problems that had led to their criminal behaviour, such as drug or gambling addictions, they were more likely to receive a custodial sanction than a non-custodial sanction. ${ }^{87}$ If this logic is then applied to the section C6 requirements, in the absence of this

\footnotetext{
85 Jessica Jacobson and Mike Hough, 'Personal Mitigation' (2008) 35 The Barrister 10. See also Joanna Shapland, Between Conviction and Sentence: The Process of Mitigation (Routledge \& Kegan Paul, 1981).

${ }^{86}$ Jessica Jacobson and Mike Hough, Mitigation: The Role of Personal Factors in Sentencing (Prison Reform Trust, 2007) 12.

${ }^{87}$ Ibid 40.
} 
information, any prosecutorial sentence recommendation made to the court is likely to be inaccurate both in type and quantum, raising issues of fairness and questions about the ability of the section C6 requirements to facilitate 'just' outcomes.

Further to questions about accuracy, Prosecutor $M$ challenged the relevance of material compiled pre-trial, claiming that such information could change significantly:

When the document is first written, a matter in mitigation might be that the offender was receiving counselling, was living at home with his family, was meaningfully employed and in a stable relationship. But by the time the sentencing comes along, the offender is no longer living at home, no longer in the relationship, no longer working, not receiving counselling, using alcohol and drugs and committing further offences. Those matters are extremely significant and can make a massive difference to the sentence.

As these comments demonstrate, it is probable that any information collated on an accused person's personal circumstances would require amendment at a date later than that of its original compilation. In light of this, it is likely that prosecutors would need additional time to review the material before using it as a basis for their sentencing recommendations. Thus, many of the already minimal resource benefits acquired by completing it at an early stage will be lost.

\section{$2 \quad$ Increased Control on Prosecutorial Discretion}

Aside from the limitations identified by participants relating to the section C6 requirements, when discussing whether implementing like guidelines in Victoria was necessary to combat the possible perceptions of pleading and resource pressures on accused persons and prosecutors, a strong degree of resistance emerged in the responses of one defence practitioner and two prosecutors. One of the prosecutors requested "no more formality ... we have good enough judgement to enter into negotiations when we want to and we don't need any more formality'. ${ }^{88}$ Similarly, Defence B claimed 'formalisation is cumbersome. We don't have to police every person in authority and reduce everything to a mechanical process'.

The key argument against formalisation identified by the Victorian participants was also a main concern identified by the two UK participants opposed to the section $\mathrm{C} 6$ requirements. They considered that control hinders

${ }^{88}$ Prosecutor G. 
flexibility and infringes on appropriate and necessary discretionary powers. Prosecutor A claimed, 'if you formalise it too much it would be difficult for us, because every case is so different. It is a very intuitive thing too because you have so many things and people to consider. It can't be just a black and white process'. Restricting flexibility through greater control on prosecutorial discretion was further criticised on the basis that it may impact on the confidentiality of discussions. Prosecutor E claimed:

Really in a lot of plea bargaining, the discussion part is not intended in any sense to bind the parties. It is only the final agreement that is binding. It is an odd thing if in, say, a murder case you have somebody who offers to plead guilty to manslaughter, but the Crown rejects it, and then they run the case at the trial on the basis that they didn't do it. So you can't have anything that is too formal.

Prosecutor W (UK) further maintained that:

If we are going to have plea bargaining ... it has got to be as informal as possible and it has to be done at a level where it can be confidential, so if it falls over, nobody is embarrassed by it, nobody feels constrained or restrained from being involved in those processes in the future.

Greater control of discretion, however, does not automatically involve revoking prosecutorial powers, nor does it require the revelation of the content of discussions, or that they be conducted in open court. Instead, as evidenced by the Guidelines, it can offer a compromise between uniformity and flexibility, whereby discretion is monitored within the parameters of legal principles and due process; 'in moderation, judicious discretion promotes justice'. ${ }^{89}$ This ideal fits within Tata's analysis of the craftwork of sentencing in the UK, where he argues that rules and discretion can be

exercised simultaneously and may only be mutually indistinguishable in the abstract ... In this way, what, in the abstract, we may term rules and discretion, should not be counterposed as opposites ... Rules and discretion are better understood as fluid, unstable and synergistic, rather than as distinct entities locked in mutual opposition. ${ }^{90}$

This type of control, which seeks to incorporate the operation of discretion and rules within a mutually constructive environment, would also be likely to

\footnotetext{
${ }^{89}$ Bibas, above n 32, 371.

${ }^{90}$ Tata, above n 7, 429-31.
} 
offer benefits that increase public awareness and understanding of plea bargaining, and reduce misperceptions of discussions. ${ }^{91}$ As Bibas observes:

What is troubling about prosecutorial discretion is not that it places discretionary power in the hands of individuals. What is troubling is that it is very often ad hoc, hidden, and insulated from public scrutiny and criticism. Many discretionary decisions require no reasoned justification. These decisions risk being inconsistent, biased, and tainted by agency costs that pull them far from the public's shared moral sense. ${ }^{92}$

The most effective way to avoid idiosyncratic reasons affecting discretionary decisions is to develop a culture and structure whereby prosecutors use their discretion consistently and in line with the ideals of justice. This is demonstrated by Miller and Wright's examination of prosecutorial discretionary charging decisions in New Orleans in the United States, which found consistent patterns of behaviour within the prosecutor's office, so that even their discretionary decisions appeared to follow an 'office common law', and similar cases were treated alike by different prosecutors. ${ }^{93}$ In fact, Miller and Wright claim that:

The recorded reasons show the influence of substantive and procedural legal doctrines, the policy priorities of supervisors, and the evidentiary hurdles of proving criminal charges - all sources that one would expect to dominate in a system that respects the rule of law. Moreover, these patterned reasons reflect something more than individual prosecutors predicting legal outcomes and operating in the shadow of the law: they show prosecutors responding to social norms and living up to group expectations about what it means to be a prosecutor in that particular office. ${ }^{94}$

Although, in this case, the culture was facilitated by an unwritten 'office common law', this type of culture would be further facilitated, and, importantly, transparent to the public, through the development of formal guidelines and policies, in line with the UK Guidelines.

\footnotetext{
91 Anthony Doob and Julian Roberts, Sentencing: An Analysis of the Public's View of Sentencing (Department of Justice, 1983); Arie Freiberg, 'The Four Pillars of Justice: A Review Essay' (2003) 36(2) Australian and New Zealand Journal of Criminology 223; David Indermaur, 'Public Perception of Sentencing in Perth, Western Australia' (1987) 20(3) Australian and New Zealand Journal of Criminology 163.

${ }^{92}$ Bibas, above n 32, 373.

${ }^{93}$ Marc L Miller and Ronald F Wright, 'The Black Box' (2008) (94) Iowa Law Review 125, 129.

${ }^{94}$ Ibid 131.
} 
Flynn argues that 'if one supports the ideal that justice needs to be seen to be done, or at the very least, have some degree of openness, then this must be applied consistently to all criminal justice processes ... [including] plea bargaining' ${ }^{95}$ On this basis, there was majority support among the Victorian interview participants for a more transparent plea bargaining process in Victoria that facilitates greater public awareness and access to prosecutorial charging decisions, albeit a support tempered by concerns about how well a non-legally educated audience would understand plea bargaining (33 out of 42 participants). As Prosecutor A argued, it 'should be totally transparent to the public. The public should definitely be informed of what goes on with negotiations. How much they understand may be difficult to establish, but we should definitely try to be open and transparent to them'. Prosecutor $\mathrm{O}$ similarly asserted that 'transparency, so far as you can be [transparent], is important. We are working for the public after all'. Prosecutor E further supported this view, claiming:

We could probably be a bit more systematised in line with the Guidelines so we had a bit more of an idea of what we are doing and then the public might view it as being more accountable. I do think we are in a position now where the degree of public accountability is probably greater than it has ever been in the past, so perhaps plea bargaining should be more systematised in that regard.

The benefits of implementing a more transparent and structured process that offers scrutiny of the decision-making powers of prosecutors are also identified by Bibas, who argues that 'the mere fear of review would discipline outliers without preventing justifiable deviation. In other words, just decisions can and should bubble up from below, so long as higher-ups are there to review and harmonize them, to check for outliers' ${ }^{96}$ Therefore, not only are any idiosyncratic discretionary decisions scrutinised, but the perception that discretionary decisions will be reviewed by a superior prosecutor will help control prosecutorial conduct and create a culture that is more supportive of transparent and accountable prosecutorial decision-making.

\section{CONCLUSION}

Despite some criticisms of the Guidelines identified (mainly) by the Victorian participants, the adoption of a similar transparent framework in Victoria could have the potential for rendering plea bargaining visible and accountable, and

\footnotetext{
${ }^{95}$ Flynn, above $\mathrm{n} 48,96$.

${ }^{96}$ Bibas, above n 32, 375.
} 
could assist in minimising some of the significant issues arising from its private nature. In particular, it could assist in alleviating perceptions that workload, resource and efficiency pressures are the main motivating factors for prosecutors entering into and accepting plea deals, by providing a level of scrutiny of these decisions. This also has the benefit of, if not alleviating some pleading pressures on accused persons, at least making these pressures more evident.

The main argument identified by those Victorian and UK participants opposed to greater controls on prosecutorial discretion in plea bargaining related to the inherent tension between flexibility and uniformity. In this regard, participants felt that in order to facilitate reasonable outcomes and consider each case's individual circumstances, prosecutorial discretion was required. However, without some uniformity, the flexible discretionary powers of prosecutors could potentially be abused, resulting in the unequal or unfair treatment of accused persons, or, at the very minimum, creating public perceptions of abuse and hidden justice. Discretion is an important component of the prosecutor's role. However it can be controlled without the control becoming unduly restrictive or inflexible. This can be achieved by implementing controls in line with the UK Guidelines, which seek to monitor discretion within the parameters of legal principle and due process by officially recognising plea bargaining, and directing and reviewing prosecutorial conduct. This shift would allow prosecutors to maintain a degree of flexibility, while also rendering their decisions more transparent. Such a move is also likely to reduce public misperceptions about, and misunderstanding of, plea bargaining. ${ }^{97}$

While this article has identified some potentially significant limitations of the UK Guidelines, particularly the possibility for the section C6 requirements to encroach upon judicial independence and squander prosecutorial resources, it has also provided strong justifications for imposing greater accountability on prosecutors in the exercise of their discretion in Victoria. As it currently operates, Victoria's plea bargaining process is surrounded by perceptions of inappropriateness and misconduct, which are largely a consequence of its private nature and the lack of public accountability and of transparency in the process. But to control prosecutorial discretion in plea bargaining in a way similar to that achieved through the Guidelines (albeit without the inclusion of the section C6 requirements) would be beneficial. It would provide a mechanism for ensuring that discussions undergo the same scrutiny and and have the same transparency as other criminal justice processes, such as the

\footnotetext{
${ }^{97}$ Bibas, above n 32; Roberts, above $\mathrm{n} 2$.
} 
trial. Furthermore, by providing a structured outline of the plea bargaining process and requirements in a legally binding policy, it would significantly reduce the potential for individualised, idiosyncratic reasons to influence prosecutorial discretion and would help create a legal culture that supports and adheres to transparent decision-making. This would be likely to promote just outcomes and enhance the transparency of the delivery of modern, efficient justice. 


\section{APPENDIX}

\section{ATTORNEY GENERAL'S GUIDELINES ON THE ACCEPTANCE OF PLEAS (REVISED 2009)}

\section{A: FOREWORD}

A1. Prosecutors have an important role in protecting the victim's interests in the criminal justice process, not least in the acceptance of pleas and the sentencing exercise. The basis of plea, particularly in a case that is not contested, is the vehicle through which the victim's voice is heard. Factual inaccuracies in pleas in mitigation cause distress and offence to victims, the families of victims and witnesses. This can take many forms but may be most acutely felt when the victim is dead and the family hears inaccurate assertions about the victim's character or lifestyle. Prosecution advocates are reminded that they are required to adhere to the standards set out in the Victim's Charter, which places the needs of the victim at the heart of the criminal justice process, and that they are subject to a similar obligation in respect of the Code of Practice for Victims of Crime.

A2. The principle of fairness is central to the administration of justice. The implementation of Human Rights Act 1998 in October 2000 incorporated into domestic law the principle of fairness to the accused articulated in the European Convention on Human Rights. Accuracy and reasonableness of plea plays an important part in ensuring fairness both to the accused and to the victim.

A3. The Attorney General's Guidelines on the Acceptance of Pleas issued on December 7, 2000 highlighted the importance of transparency in the conduct of justice. The basis of plea agreed by the parties in a criminal trial is central to the sentencing process. An illogical or unsupported basis of plea can lead to an unduly lenient sentence being passed, and has a consequential effect where consideration arises as to whether to refer the sentence to the Court of Appeal under section 36 of the Criminal Justice Act 1988. 
A4. These Guidelines, which replace the Guidelines issued in October 2005, give guidance on how prosecutors should meet these objectives of protection of victims' interests and of securing fairness and transparency in the process. They take into account paragraphs IV.45.4 and following of the Consolidated Criminal Practice Direction, amended May 2009 and the guidance issued by the Court of Appeal (Criminal) Division in $R v$ Beswick [1996] 1 Cr.App.R. 343, $R$ v Tolera [1999] 1 Copyright App R 25 and $R v$ Underwood [2005] 1 Copyright App R 178. They complement the Bar Council Guidance on Written Standards for the Conduct of Professional Work issued with the 7th edition of the Code of Conduct for the Bar of England and Wales and the Law Society's Professional Conduct Rules. When considering the acceptance of a guilty plea prosecution advocates are also reminded of the need to apply the Farquharson Guidelines on the Role and Responsibilities of the Prosecution Advocate.

A5. The Guidelines should be followed by all prosecutors and those persons designated under section 7 of the Prosecution of Offences Act 1985 (designated caseworkers) and apply to prosecutions conducted in England and Wales.

\section{B: General Principles}

B1. Justice in this jurisdiction, save in the most exceptional circumstances, is conducted in public. This includes the acceptance of pleas by the prosecution and sentencing.

B2. The Code for Crown Prosecutors governs the prosecutor's decisionmaking prior to the commencement of the trial hearing and sets out the circumstances in which pleas to a reduced number of charges, or less serious charges, can be accepted.

B3. When a case is listed for trial and the prosecution form the view that the appropriate course is to accept a plea before the proceedings commence or continue, or to offer no evidence on the indictment or any part of it, the prosecution should whenever practicable speak to the victim or the victim's family, so that the position can be explained. The views of the victim or the family may assist in informing the prosecutor's decision as to whether it is the public interest, as defined by the Code for Crown Prosecutors, to accept or reject the plea. The victim or victim's family should then be kept informed and decisions explained once they are made at court. 
B4. The appropriate disposal of a criminal case after conviction is as much a part of the criminal justice process as the trial of guilt or innocence. The prosecution advocate represents the public interest, and should be ready to assist the court to reach its decision as to the appropriate sentence. This will include drawing the court's attention to:

Any victim personal statement or other information available to the prosecution advocate as to the impact of the offence on the victim;

Where appropriate, to any evidence of the impact of the offending on a community;

Any statutory provisions relevant to the offender and the offences under consideration;

Any relevant sentencing guidelines and guideline cases; and

The aggravating and mitigating factors of the offence under consideration.

B5. The prosecution advocate may also offer assistance to the court by making submissions, in the light of all these factors, as to the appropriate sentencing range. In all cases, it is the prosecution advocate's duty to apply for appropriate ancillary orders, such as anti-social behaviour orders and confiscation orders. When considering which ancillary orders to apply for, prosecution advocates must always have regard to the victim's needs, including the question of his or her future protection.

\section{C: The BAsis of PleA}

$\mathrm{C} 1$. The basis of a guilty plea must not be agreed on a misleading or untrue set of facts and must take proper account of the victim's interests. An illogical or insupportable basis of plea will inevitably result in the imposition of an inappropriate sentence and is capable of damaging public confidence in the criminal justice system. In cases involving multiple defendants the bases of plea for each defendant must be factually consistent with each other.

C2. When the defendant indicates an acceptable plea, the defence advocate should reduce the basis of the plea to writing. This must be done in all cases save for those in which the defendant has indicated that the guilty plea has been or will be tendered on the basis of the prosecution case.

C3. The written basis of plea must be considered with great care, taking account of the position of any other relevant defendant where appropriate. The 
prosecution should not lend itself to any agreement whereby a case is presented to the sentencing judge on a misleading or untrue set of facts or on a basis that is detrimental to the victim's interests. There will be cases where a defendant seeks to mitigate on the basis of assertions of fact which are outside the scope of the prosecution's knowledge. A typical example concerns the defendant's state of mind. If a defendant wishes to be sentenced on this basis, the prosecution advocate should invite the judge not to accept the defendant's version unless he or she gives evidence on oath to be tested in crossexamination. Paragraph IV.45.14 of the Consolidated Criminal Practice Direction states that in such circumstances the defence advocate should be prepared to call the defendant and, if the defendant is not willing to testify, subject to any explanation that may be given, the judge may draw such inferences as appear appropriate.

C4. The prosecution advocate should show the prosecuting authority any written record relating to the plea and agree with them the basis on which the case will be opened to the court. If, as may well be the case, the basis of plea differs in its implications for sentencing or the making of ancillary orders from the case originally outlined by the prosecution, the prosecution advocate must ensure that such differences are accurately reflected in the written record prior to showing it to the prosecuting authority.

C5. It is the responsibility of the prosecution advocate thereafter to ensure that the defence advocate is aware of the basis on which the plea is accepted by the prosecution and the way in which the prosecution case will be opened to the court.

C6. In all cases where it is likely to assist the court where the sentencing issues are complex or unfamiliar the prosecution must add to the written outline of the case which is served upon the court a summary of the key considerations. This should take the form of very brief notes on:

Any relevant statutory limitations

The names of any relevant sentencing authorities or guidelines the scope for any ancillary orders (e.g. concerning anti-social behaviour, confiscation or deportation will need to be considered.

The outline should also include the age of the defendant and information regarding any outstanding offences.

C7. It remains open to the prosecutor to provide further written information (for example to supplement and update the analysis at later stages of the case) 
where he or she thought that likely to assist the court, or if the judge requests it.

C8. When the prosecution advocate has agreed the written basis of plea submitted by the defence advocate, he or she should endorse the document accordingly. If the prosecution advocate takes issue with all or part of the written basis of plea, the procedure set out in the Consolidated Criminal Practice Direction (and in Part 37.10(5) of the Criminal Procedure Rules) should be followed. The defendant's basis of plea must be set out in writing identifying what is in dispute; the court may invite the parties to make representations about whether the dispute is material to sentence; and if the court decides that it is a material dispute, the court will invite further representations or evidence as it may require and decide the dispute in accordance with the principles set out in $R v$ Newton, 77 Cr.App.R.13, CA. The signed original document setting out the disputed factual matters should be made available to the trial judge and thereafter lodged with the court papers, as it will form part of the record of the hearing.

C9. Where the basis of plea cannot be agreed and the discrepancy between the two accounts is such as to have a potentially significant effect on the level of sentence, it is the duty of the defence advocate so to inform the court before the sentencing process begins. There remains an overriding duty on the prosecution advocate to ensure that the sentencing judge is made aware of the discrepancy and of the consideration which must be given to holding a Newton hearing to resolve the issue. The court should be told where a derogatory reference to a victim, witness or third party is not accepted, even though there may be no effect on sentence.

C10. As emphasised in paragraph IV.45.10 of the Consolidated Criminal Practice Direction, whenever an agreement as to the basis of plea is made between the prosecution and defence, any such agreement will be subject to the approval of the trial judge, who may of his or her own motion disregard the agreement and direct that a Newton hearing should be held to determine the proper basis on which sentence should be passed.

C11. Where a defendant declines to admit an offence that he or she previously indicated should be taken into consideration, the prosecution advocate should indicate to the defence advocate and the court that, subject to further review, the offence may now form the basis of a new prosecution. 


\section{D: SENTENCE INDICATIONS}

D1. Only in the Crown Court may sentence indications be sought. Advocates there are reminded that indications as to sentence should not be sought from the trial judge unless issues between the prosecution and defence have been addressed and resolved. Therefore, in difficult or complicated cases, no less than seven days notice in writing of an intention to seek an indication should normally be given to the prosecution and the court. When deciding whether the circumstances of a case require such notice to be given, defence advocates are reminded that prosecutors should not agree a basis of plea unless and until the necessary consultation has taken place first with the victim and/or the victim's family and second, in the case of an independent prosecution advocate, with the prosecuting authority.

D2. If there is no final agreement about the plea to the indictment, or the basis of plea, and the defence nevertheless proceeds to seek an indication of sentence, which the judge appears minded to give, the prosecution advocate should remind him or her of the guidance given in $R v$ Goodyear (Karl) [2005] EWCA 888 that normally speaking an indication of sentence should not be given until the basis of the plea has been agreed or the judge has concluded that he or she can properly deal with the case without the need for a trial of the issue.

D3. If an indication is sought, the prosecution advocate should normally enquire whether the judge is in possession of or has access to all the evidence relied on by the prosecution, including any victim personal statement, as well as any information about relevant previous convictions recorded against the defendant.

D4. Before the judge gives the indication, the prosecution advocate should draw the judge's attention to any minimum or mandatory statutory sentencing requirements. Where the prosecution advocate would be expected to offer the judge assistance with relevant guideline cases or the views of the Sentencing Guidelines Council, he or she should invite the judge to allow them to do so. Where it applies, the prosecution advocate should remind the judge that the position of the Attorney General to refer any sentencing decision as unduly lenient is unaffected. In any event, the prosecution advocate should not say anything which may create the impression that the sentence indication has the support or approval of the Crown. 


\section{E: Pleas in Mitigation}

E1. The prosecution advocate must challenge any assertion by the defence in mitigation which is derogatory to a person's character, (for instance, because it suggests that his or her conduct is or has been criminal, immoral or improper) and which is either false or irrelevant to proper sentencing considerations. If the defence advocate persists in that assertion, the prosecution advocate should invite the court to consider holding a Newton hearing to determine the issue.

E2. The defence advocate must not submit in mitigation anything that is derogatory to a person's character without giving advance notice in writing so as to afford the prosecution advocate the opportunity to consider their position under paragraph E1. When the prosecution advocate is so notified they must take all reasonable steps to establish whether the assertions are true. Reasonable steps will include seeking the views of the victim. This will involve seeking the views of the victim's family if the victim is deceased, and the victim's parents or legal guardian where the victim is a child. Reasonable steps may also include seeking the views of the police or other law enforcement authority, as appropriate. An assertion which is derogatory to a person's character will rarely amount to mitigation unless it has a causal connection to the circumstances of the offence or is otherwise relevant to proper sentencing considerations.

E3. Where notice has not been given in accordance with paragraph E2, the prosecution advocate must not acquiesce in permitting mitigation which is derogatory to a person's character. In such circumstances, the prosecution advocate should draw the attention of the court to the failure to give advance notice and seek time, and if necessary, an adjournment to investigate the assertion in the same way as if proper notice had been given. Where, in the opinion of the prosecution advocate, there are substantial grounds for believing that such an assertion is false or irrelevant to sentence, he or she should inform the court of their opinion and invite the court to consider making an order under section 58(8) of the Criminal Procedure and Investigations Act 1996, preventing publication of the assertion.

E4. Where the prosecution advocate considers that the assertion is, if true, relevant to sentence, or the court has so indicated, he or she should seek time, 
and if necessary an adjournment, to establish whether the assertion is true. If the matter cannot be resolved to the satisfaction of the parties, the prosecution advocate should invite the court to consider holding a Newton hearing to determine the issue.

\section{Her Majesty's Attorney General}

[Issued 5 November to take effect 1 December 2009] 